\title{
Budhigandaki Hydroelectric Project is Unlikely to be Implemented as Recommended by Tractebel Engineering
}

\section{Dr. Hari Man Shrestha}

\begin{abstract}
Tractebel Engineering SA France has recommended $263 \mathrm{~m}$ high double curvature arch dam for the Budhigandaki Hydroelectric Project for generation of $1200 \mathrm{MW}$. The author, based on findings of the Tractebel's feasibility study itself, gives reasons why the project is unlikely to be implemented as recommended by the consultant. Further, the author raises the question with the government why this project was declared as one of the projects of national pride and was ready for committing to funding beforehand for the preparation of detail design, tender documents and tender drawings in a single package contract along with the feasibility study when the investment decision could only be taken after ascertaining the soundness/ attractiveness of the project on technical, economical, financial and socio-environmental grounds through feasibility and Environmental Impact Assessment (EIA) studies. The author also believes that the project could become more attractive if the downstream benefits from flow regulation in existing irrigation project in India could be accounted for and two potential hydroelectric projects in Nepal at the downstream reaches could be implemented first to derive additional power benefits in these two projects from flow regulation.
\end{abstract}

Keywords: Budhigandaki Hydroelectric Project, Feasibility, EIA, Nepal

\section{Study Background of Budhigandaki HEP}

The Budhigandaki Hydroelectric Project 1 (Budhigandaki HEP) was first identified by the author in the late sixties during the course of desk study on maps aimed at preparation of proposal for securing financial support for investigation of the potential storage dam projects in the Gandaki Power Development Study (see reference no. 5 quoted in the paper \# 153 entitled "Water Power Potential of Nepal: its theoretical and technical limits" presented by the author in the VII World Power Conference held in August 1968, Moscow). The project concept is also documented in the Master Plan of Hydroelectric Power Development in Nepal prepared by JICA in September, 1974. At that time the Budhigandaki project was planned for a rock fill dam of $135 \mathrm{~m}$ high above stream bed with an installed capacity of 200 MW for gross energy generation of 1330 GWh per year. During Basin Master Plan study conducted towards the end of seventies with the financial support under United Nations Development Program, this project site was recommended for an earth and rock fill dam of $225 \mathrm{~m}$ high for generation of 500 MW (Refer Gandaki River Basin Power Study, July 1979 by Snowy Mountains Engineering Corporation). In the early eighties, with the financial and expatriate support through CIDA from the Canadian government, the then Electricity Department of HMG/N carried out prefeasibility study of this project (Refer Budhigandaki Hydroelectric Project Prefeasibility Study, April 1984), according to which the following are the important features/ parameters of the project:

\begin{tabular}{|c|r|}
\hline Dam height: & \\
\hline Above river bed & $200 \mathrm{~m}$ \\
\hline Above foundation & $225 \mathrm{~m}$ \\
\hline Dam type & Embankment \\
\hline
\end{tabular}

\begin{tabular}{|l|r|}
\hline Full Supply Level (FSL) & $520 \mathrm{~m}$ \\
\hline Gross storage & $3320 \times 10^{6} \mathrm{~m}^{3}$ \\
\hline Powerhouse & Underground \\
\hline Rated head & $185 \mathrm{~m}$ \\
\hline Total rated discharge & $430 \mathrm{~m}^{3} / \mathrm{s}$ \\
\hline Turbine & Francis, $4 \times 150 \mathrm{MW}$ \\
\hline Generator & $2495 \mathrm{GWh} / \mathrm{yr}$ \\
\hline Energy generation (average) & 6556 (in 1982) \\
\hline Affected people & $220 \mathrm{kV}, 66 \mathrm{~km}$ long \\
\hline Transmission line to Kathmandu & 1.06 (quite marginal) \\
\hline $\begin{array}{l}\text { Incremental benefit cost ratio } \\
\text { (raising full supply level from } 520 \mathrm{~m} \\
\text { to } 540 \text { m) }\end{array}$ & \\
\hline
\end{tabular}

Table1: Important features of the Project.

India's Interest on the Project and Citing it as one of the Projects of National Pride by GoN With the flow regulation by the Budhigandaki HEP, the flow availability at the Gandak Barrage increases substantially particularly in the dry months from December to May and the irrigation canals can run at fuller capacities in these months thereby increasing the irrigation potential. This is automatically accruable downstream irrigation benefits to India without incurring any additional cost on new infrastructures. As these benefits are quite high, India's attachment of interest on this project is quite apparent. India wishes to derive these benefits free of cost by naming the project as hydroelectric, but is very clear that any downstream benefits from flow regulation is possible only by allowing submergence in the river valley upstream and displacing the people living there.

India showed its first interest to this project during the visit of the then prime minister of India Chandra Shekhar to Nepal after the political change of 1990, in the course of separate discussion between water resources secretaries of two countries. In that meeting, the Indian counterpart presented several projects in Nepal for joint survey and investigation, in 
response to his suggestions, the Nepalese counterpart mentioned that the projects suggested by the Indian side had already been investigated and as a proof the Nepalese side showed reports including 1984 prefeasibility report of $600 \mathrm{MW}$ Budhigandaki Hydroelectric Project. The Indian counterpart showed keen interest on this project and took a set of the study report on this project stating that it could be included for possible cooperation. Accordingly, this project was mentioned in the joint communique issued by both the countries at the end of the prime minister's visit (Refer article entitled "Personnel Reflections: Nepal - India Water Relations" by the then Water Resources Secretary B. K. Pradhan in "Nepal - India Water Resources Relationships - Challenges, 2009"). In actuality, the Indian side wanted to apply Bhutan model in Nepal starting from this project.

This project was further discussed during the Second Meeting of the Indo-Nepal Sub- commission on Multiple Uses of Water Resources held in April 1991. During this meeting India also offered to complete the investigations.

When the Nepalese prime minister G. P. Koirala made his first official call to New Delhi in December 1991, regarding this project even a time framed decision was taken up to conduct field survey by a joint team of experts and to complete these works by June 1992 and prepare the Detailed Project Report (DPR) in order that the construction can start by 1994. However, the joint team of experts of Nepal and India during its first meeting of February 24-27, 1992, although agreed on the scope of works for additional surveys/ investigations including assessment of downstream benefits required for preparation of DPR, could not agree on the modalities to conduct the field investigation works and preparation of DPR. In that meeting the Indian side reconfirmed the offer made by GoI to finance the additional survey/ investigation works and preparation of DPR, but expressed that India would prepare the DPR on a turn-key basis in association with the Nepalese personnel deputed from the then HMG/N by opening a project office under GoI in Kathmandu, Nepal. The Nepalese team (the author was the team leader from the Nepalese side) expressed that regardless of the source of financing, the project office would have to be established under the aegis of HMG/N as it was a Nepalese project. This point of contention recorded during the meeting became a reason for shelving this project up to a period before the start of Dr. Bhattarai's government, although in several previous meetings the project could appear in the form of an agenda item or action plan.

It is only in the fiscal year 2010/11, with the onset of acute energy crisis during dry season, the Nepal Electricity Authority (NEA) reinitiated its studies due to ability to generate dry season energy and proximity to Kathmandu (the major load centre of the country). The Ministry of Energy also issued the survey license of this project to NEA. In the mean time, the GoN gave a high priority to this project citing it as one of the projects of national pride (Refer NEA Year-Book of Fiscal Year 2011/012). Consequently, NEA received the fund from GoN towards the cost of consulting services for feasibility study and detail design of the project with the overall objective to carry out necessary field investigation and upgrade the existing prefeasibility level study of the project to a feasibility level, prepare a detailed design and tender documents and tender drawings, and carry out environmental impact assessment, social impact assessment and prepare environmental management plan. Accordingly, applying the QCBS selection method, the contract agreement for the consulting services was signed between NEA and Tractebel Engineering S. A., France in December 2012 with a contract amount of Euro 4,207,804 in foreign currency and NRs. 470,907,398 in local currency. But it is wondering why the GoN attached high priority to this HEP declaring it, beforehand, as a project of national pride for which feasibility is yet to be established from the economic, financial and socio-environmental points of view.

\section{Present Feasibility Study and Its Findings}

The present feasibility study of Budhigandaki HEP has been carried out by Tractebel Engineering S. A. (France) in association with JADE Consult Pvt. Ltd. (Nepal) as a Sub-consultant with an effective date of commencement of the services on February 1, 2013 under the aegis of Budhigandaki HEP Development Committee formed by the GoN specially for this project purpose. The findings of the study presented here are based on the Draft Final Report submitted to Budhigandaki Hydroelectric Project Development Committee (BHEPDC) on November 1, 2014, a set of copies of which has been sent by the BHEPDC to the author for overall review on 2071/08/07 BS (November 23, 2014 AD). It contains 16 main volumes including the Volume - 6 Appendix - 1: Seismic Hazard Assessment. The principle features/ parameters of the project and major findings are as follows:

\begin{tabular}{|l|r|}
\hline Dam height & $263 \mathrm{~m}$ \\
\hline Dam type & Double curvature Arch \\
\hline Full Supply Level (FSL) & $540 \mathrm{~m}$ \\
\hline Gross storage & $4467 \times 10^{6} \mathrm{~m}^{3}$ \\
\hline Submergence at FSL & $63 \mathrm{~km}^{2}$ \\
\hline Power house & Outdoor \\
\hline Rated head at rated water level & $200 \mathrm{~m}$ \\
\hline Total rated discharge & $672 \mathrm{~m}^{3} / \mathrm{s}$ \\
\hline Turbine & Francis, $6 \times 200 \mathrm{MW}$ \\
\hline Generator & Vertical shaft, $6 \times 235 \mathrm{MVA}$ \\
\hline Energy generation (average) & $3383 \mathrm{GWh} / \mathrm{yr}$ \\
\hline Affected people (Total) & 45,188 \\
\hline
\end{tabular}

Table 2: Principle features of the Project.

The findings of the study are based on the conditions/assumptions of analysis given below:

- In both economic and financial costs, environment costs have been excluded, while for economic cost contingency costs have also been excluded.

- For benefits, in both economic and financial analysis, fuel cost savings were accounted for. In addition, for financial analysis revenues 
from sales to Nepalese customers a rate of 7.95 $\mathrm{NRs} / \mathrm{kWh}$ has been applied, while for export of excess energy the rate applied was $7.43 \mathrm{NRs} /$ $\mathrm{kWh}$. The currency conversion rate used is NRs 1=US \$ 0.0102. However, for economic analysis, particularly for the Nepalese uses nonincremental and incremental customer benefits with aggregate rate of as much as $23.45 \mathrm{US} \mathrm{c} / \mathrm{kWh}$ has been applied.

The calculated economic and financial indicators (EIRR and FIRR) based on these conditions/ assumptions are respectively $12.7 \%$ and $8.8 \%$. The other highlights given in the report are:

- The financial rate of return would be substantially lower if the effects of fuel cost savings attributable to Budhigandaki HEP were to be eliminated from the analysis.

- For IPP developers expecting return of equity values of between $15 \%$ and $20 \%$, the equivalent cost per unit of energy supplies would be between 17.6 US $\mathrm{c} / \mathrm{kWh}$ and $22.2 \mathrm{US} \mathrm{c} / \mathrm{kWh}$ which are substantially higher than the revenues that the NEA could receive from Nepalese customers or from exports to India, and would, therefore, potentially prejudice the financial stability of the company. The extent to which any commercial lender would accept such an arrangement is also questionable.

The newspaper states that the Tractebel Engineering has already submitted the final feasibility report although late due to delays in receiving the reviewers' notes from the concerned agencies including the Water and Energy Commission Secretariat (WECS) and subject-specific individual experts. As everybody knows that the requirements to consider the suggestions/ comments from the reviewers/stakeholders to finalize the report are generally just the contractual obligation and/or formality. Based on review notes, some refinements, corrections of overlooked errors, etc might have been done during finalization of the report, but major parameters/findings cannot be abruptly changed, and therefore, they must be principally the replication of the draft final report.

\section{Why it is Unlikely that the Project will be Implemented as Recommended by the Tractebel Engineering}

Firstly, as is evident from the above given facts, the project is clearly unfeasible particularly from the financial view point. Over and above it is also clear that during project evaluation over-estimate of benefits and under-estimate of costs have been applied. For example, the costs of mitigation measures of negative consequences emerged from the implementation of the project must be a part of the project cost such as the cost of re-regulation facilities and the costs associated with socio-environment. They have neither been included in the economic analysis nor in the financial analysis. Similarly, the contingency costs to be allocated for unforeseen physical work items have not been included in the economic analysis. These costs alone comprising of $21 \%$ for environment impact mitigations and $8 \%$ for contingencies (excluding the cost of re-regulation facilities which have not yet been estimated) constitute cumulatively $29 \%$ of the total capital expenditure estimated. On the other hand, during assessment of benefits, in lieu of adopting usual practice of assessment of benefit by way of comparison with cheapest alternatives available, the avoided cost of costly HFO has been taken as benefits besides taking into account the factors such as the non-incremental and incremental customer benefits as economic benefits rather than the sales revenue from the Nepalese customers, as adopted for export to India raising the aggregate unit benefit rate from Nepalese customers to as much as 23.45 US c/kWh. In the Nepalese context, there do exist the following two obvious alternatives too for fulfilling the Nepalese requirements:

- Through import of electricity from Indian system, and

- Through development of similar hydropower project in Nepal such as the 750 MW West Seti Storage HEP.

Secondly, a simplistic calculation using the following table constituted from the data presented in the report clearly shows that the installed capacity of 1200 MW recommended by the consultant is not optimum.

\begin{tabular}{|l|l|l|l|l|}
\hline Installed capacity (MW) & 600 & 800 & 1000 & 1200 \\
\hline Cost (million US \$) & 2357 & 2422 & 2486 & 2550 \\
\hline Energy output (GWh/yr) & 3163 & 3276 & 3346 & 3383 \\
\hline
\end{tabular}

Table 3: Comparative features.

As could be seen from the table that the incremental energy output per year drastically reduced from 113 $\mathrm{GWh} / \mathrm{yr}$ to $37 \mathrm{GWh} / \mathrm{yr}$ with addition of $200 \mathrm{MW}$ unit in each step, while the corresponding incremental cost remains almost constant giving the incremental energy cost per kWh unacceptably high as much as 22.7 US cents (almost 2.84 times the sales tariff) for the last step addition of $200 \mathrm{MW}$ unit when a typical $13 \%$ anualization factor comprising of capital recovery factor, $\mathrm{O} \& \mathrm{M}$ and replacement cost factors has been used.

Thirdly, regarding the dam type, no financer in the world will probably be eager to invest on a double curvature arch dam as high as $263 \mathrm{~m}$ located in the region of fragile Himalayan geology with high seismicity. Following points need to be considered if the project is to be made practically happen in terms 
of dam type.

- There is not yet a single example of such a high double curvature arch dam constructed in the Himalayan region.

- When considered the devastation that could occur at downstream reaches due to instantaneous failure of dam with impounding a water volume of as much as about 4500 million $\mathrm{m}^{3}$ (gross), it cannot be compromised with some cost savings (The report itself mentions that the dam failure in case of concrete dam is more instantaneous and complete than in case of embankment dams).

- Tehri dam (located in Bhagirathi river in the state of Uttarakhanda in India) with a height of $261 \mathrm{~m}$ and $1000 \mathrm{MW}$ installed capacity (almost exactly of the same magnitude as Budhigandaki HEP), which is called an engineering marvel of modern India, was constructed as an earth cored rock fill embankment dam although there was a tremendous increase in cost over 40 times between 1976 and 2006. It is also located in the Himalayan region as is the proposed Budhigandaki dam. During construction of this dam the concerned authorities have addressed successfully several engineering challenges and concerns towards development of the dam in the Himalayan region. Earth and rock fill dams are naturally more earthquake resistant than concrete dams due to their large inertia, high degree of flexibility. Hence, this type of dam is preferred over concrete dams in the high seismic zone like Uttarakhanda or in Nepal. In Tehri dam for additional safeties, a fine sand layer has been provisioned on the upstream face of the core wall that in the unlikely event of cracking of core, sand will be washed into the cracks to seal them and also two inspection galleries are equipped in the dam body to monitor the seepage and seismic activities during operation (In general there should have not been any galleries in earth and rock fill dams, but are equipped in Tehri dam for the additional safety. Refer "Tehri Dam: An Engineering Marvel” by Basistha Raj Adhikari in Issue No. 5 of Hydro Nepal). Tarbella dam with a height of $143 \mathrm{~m}$, again located on the Indus river in the Himalayan region in Pakistan has also been implemented as an embankment dam.

- A number of proposed dams in India within the Brahmaputra river again located in the Himalayan region (Dihang dam - $296 \mathrm{~m}$, Subansiri dam - 257 $\mathrm{m}$, Tipaimukh dam $-161 \mathrm{~m}$ ) all are rock fill with impervious core (refer Indo-Bangladesh Task Force Report on Flood Management, June 1990).

- During initial phases of studies for Pancheswor (315 m high dam) and Karnali (Chisapani - 270 $\mathrm{m}$ high dam) Multipurpose Projects located respectively in western border of Nepal with India and in western Nepal, the concrete dam alternatives were proposed. However, during the subsequent phases of studies, when more and more in-depth information from further investigations were accumulated the results were in favour of the dam types with rock or gravel filled embankment with impervious core at the centre became apparent.

The reasons given for Karnali (Chisapani) project are:

i An embankment dam can adjust to foundation movements.

ii None of the alternatives is considered technically unacceptable. Their technical merits relate mainly to the inferred site geological conditions, i.e., the degree of certainty in the interpretation and the impact of variations between actual and inferred upon the design and hence on the cost of alternatives. The concrete dam is the most sensitive in this respect and indeed some experts would agree that it is, in fact, technically unacceptable as to the ultimate practicability and as constructed cost of the concrete dam compared to embankment dam.

\section{There is a Space to Make the Project More Attractive}

As are evident from the foregoings, the project is not going to be attractive in isolation in terms of installed capacity, the scale and type of dam recommended. Added benefits accruable at downstream reaches from the flow regulation are the major attraction of the project. Flood control benefits may not be large due to the reason that it is a sub-tributary of overall Gandaki river system and has a catchment area of only about $15 \%$ or less before crossing the Nepal-India border. However, power and irrigation benefits will be quite substantial. The existing Gandaki irrigation system in India can immediately derive the benefits from the use of augmented flow in dry months, while for deriving added benefits from power/energy production, the potential hydropower projects at the downstream reaches in Nepal are to be constructed first (i.e., before Budhigandaki HEP).

There are two potential hydropower projects - one on Trishuli river in the reach between Budhigandaki confluence and Marsyangdi confluence which is in any way a must for re-regulating the peak release from the proposed Budhigandaki HEP, if the project is to be really implemented. The other is on the Saptagandaki at Deoghat. Of them, the later has already been not only thoroughly studied, but also had reached the implementation stage, however due to attention and noise diverted around Arun- 3 HEP in the eighties and early nineties, the project is still lying in the shelf; the other one requiring feasibility study may suitably be located in the present day context at the upstream reach from the cable way station to Manakamana or as suggested in the previous master plan studies either at Bhomlichok or at Mugling. This project will be more appropriate for re-regulating facility than that has 
been suggested in the Tractebel's report for locating in the Budhigandaki river course just upstream of its confluence with Trishuli River at Benighat.

The added benefits of flow regulation accruable due to Budhigandaki HEP in these potential downstream hydropower projects and in the existing Gandak irrigation system could make the planned Budhigandaki HEP more attractive.

\section{Concluding Remarks}

Budhigandaki HEP is not a small and simple project, it is a world class project in terms of every aspect including the dam height, impoundment volume, geological complexity, requirement of seismic consideration, area to be submerged, socioenvironmental implications, etc. Thus, it requires more serious study before hastily moving into detail design, preparation of tender documents and drawings. For deciding the dam type and height, scale of development, revisiting deeply once more the prefeasibility study of 1984 is desirable in pari-passu with seeking the advice from the panel of experts having experience in the Himalayan geological and seismic conditions for confirming the dam type in particular.

It may be true that half of the India's one billion dollar line of credit will be earmarked for the Budhigandaki HEP as stated in the SB Pun's article entitled "Utilizing India's One Billion Dollar Line of Credit" (Refer Issue No. 16 of Hydro Nepal Journal), but not to speak of $50 \%$, even with $100 \%$ allocation of the said line of credit only $40 \%$ of the estimated project cost of US $\$ 2550$ million could be met. For the rest commercial lending (either fully or partially) will, in any way, be required. Moreover, the soft loans are generally tailored with a number of conditions that leads to cost overrun. Therefore, the dream of the project will be mere mirage unless the project is made commercially viable.

For making the project more attractive, the only way is to take into account the downstream flow regulation benefits. In this context, for the automatically derivable benefits in the existing
Gandak irrigation system, there need to be clearcut commitment first from the Indian side what contribution they can make in exchange of these benefits towards the costs of creation of dam/storage reservoir and associated costs in mitigating the socioenvironmental impacts that are going to be caused from the submergence. Secondly, the feasibility study of Saptagandaki HEP needs to be updated/upgraded incorporating the assessment of the added benefits to the project due to flow regulation by Budhigandaki HEP. Thirdly, the feasibility study of a downstream re-regulating base load energy generating hydropower dam project of moderate height in the river stretch of Trishuli lying between the confluences with Budhigandaki and Marsyangdi is to be carried out. This dam site should suitably be selected at upstream of cable car station to Manakamana not to disturb the existing cableway facility, while powerhouse could be located at downstream reach from the Marsyangdi confluence on the left bank of Trishuli-Ganga along Mugling-Bharatpur road or at the dam toe itself near Bhomlichok.

Dr. Hari Man Shrestha holds M. Sc. (Hydropower Engineering, September 1957 - July 1963) and Ph. D. (Technical Science, September 1963 - March 1966) from Moscow Power Institute, the then USSR. He is the first Nepali Ph. D. in Technical Science (Engineering). Dr. Shrestha, while conducting an academic research for his Cadastre of Hydropower Resources Ph.D. thesis at the Moscow Power Institute (then USSR), in $1966 \mathrm{AD}$, came up with an exciting finding, which showed Nepal's theoretical hydropower potential at an 83,00o MW. He has a wealth of experience spanning over 40 years in the fields of hydropower and water resources, having worked in different capacities including the Executive Secretary (Chief) of Water and Energy Commission Secretariat (WECS) and also an advisor to Water and Energy Commission (WEC) during his tenure of services in the Government.

Corresponding address: ssudhii@gmail.com 